\title{
Processing of Gattar Pilot Plants Tailing Piles for Re- moving Uranium Residual, Eastern Desert, Egypt
}

\author{
Reda A Gazala and Mohamed S Nagar* \\ Nuclear Materials Authority, El-Maadi, Egypt
}

Submission: December 19, 2017; Published: January 08, 2018

*Corresponding author: Mohamed S Nagar, Nuclear Materials Authority, El-Maadi, Cairo, Egypt, Tel: 002 01092622782; Email: mf_nagar@yahoo.com

\begin{abstract}
Gattar uranium mineralization in eastern desert is of comparatively low grade containing about $300 \mathrm{ppm}$ uranium. A pilot plant for leaching of uranium and produce commercial yellow cake was set up in 2000. A huge amount of residues resulted during leaching process with uranium assay about 85 ppm uranium. The present study was performed mainly to leach of uranium from the already present residues resulted from previous uranium vat leaching from gattar uranium mineralization. Vat leaching, is a static process in which the mineralized granite is crushed, disposed in vats and irrigated with a sulfuric acid solution with proper concentration to leach the uranium. The flow sheet adopted is of sulfuric acid leach-ion exchange process, the leaching was optimized to leach uranium with low acid concentration. Uranium is finally recovered by precipitation with sodium hydroxide. The uranium leaching from the residues (tailings) were examined by re-crashed coarse size via a batch experiments as a function of contact time, grind size, L/S ratio and lixiviant concentration at ambient temperature. To verifying the feasibility of uranium leaching in large-scale applications, column leaching of uranium was carried out. The results indicate the feasibility of treating the residue of the vat leaching through dynamic leaching recovery of about $83 \%$ of uranium in the residue was obtained using a $1.5 \% \mathrm{w} / \mathrm{w}$ consumption of acid, grain size is $<10 \mathrm{~mm}$ and total liquid-solid ratio is $0.8 \mathrm{~m}^{3} / \mathrm{t}$.
\end{abstract}

Keywords: Residue; Uranium; Leachability; Granite

\section{Introduction}

Heap leaching is useful for the treatment of low-grade dumps, and for small mineralized bodies located at a considerable distance from conventional processing facilities. Heap leaching does not require a large capital expenditure for equipment. Agitation and liquid-solid separation equipment are also not needed in heap leaching operation, since solution effluent from the pile is usually clear. The rise in uranium prices has resulted in renewed exploration, expansion and construction of new projects such as Langer Heinrich (Namibia), Keyelekera (Malawi), Ezulwini (South Africa), and Buffelsfontein (South Africa). There is also renewed focus on exploration of previously uneconomical ores and wastes such as Rossing (heap leaching of low grade ore) and Buffelsfontein (treatment of pyrite-gold tailings). Expansion through heap leaching is being investigated at Ranger (Australia) and construction of a heap leach plant at Arlit (Niger) [1]. Heap leaching has become an important processing technique in uranium ore processing industry in China, due to the advantages such as lower capital expenditure, simpler techniques and shorter construction period [2,3].

Besides, in heap leaching the relatively coarse size of the left tailings can help in minimizing dusting and wind erosion problems but recent experimental evidence suggests that in fact leaching from large particles occurs only at the surface and hence low recovery were considered increasing amounts of uranium that have been released to the environment [4]. Solution purification and precipitation facilities may be used in a mobile or portable facility to produce a product suitable for shipment [5]. In Gattar experimental pilot unit for yellow cake preparation from mineralized granite of Gattar area (Eastern Desert, Egypt), The process have actually involved the uranium mineralization loading into vat leaching pad using the percolation technique. In this procedure, the distribution of the solution can be controlled during percolation leaching; in manure that uranium extraction are good and tend to be higher than that in heap leaching. From the obtained pregnant leach liquor, uranium was recovered via anionic exchange resin to be finally precipitated as sodium diuranate. The vat leaching applied upon the relatively coarse size; a matter which would help in minimizing both dusting and wind erosion problems. It has to be indicted herein that many variables can affect the results obtained from vat leaching in Gattar project, but the most important variable are the coarse size and solution distribution within the uranium mineralization bed.

On the other hand, it is also necessary to indicate that the input uranium mineralization used in the leaching vat assays $300 \mathrm{ppm}$ uranium in average and its grain size ranged from 50 
to $10 \mathrm{~mm}$. The leaching efficiency in Gattar unites ranged from $65-70 \%$. Low recovery was considered increasing amounts of uranium that have been released to the environment. This low leaching efficiency although leaching time for the heap pad reach to 73 day can be related to the large grain size of the ore. Recent experimental evidence suggests that in fact leaching from large particles occurs only at the surface and in subsurface regions, which are accessible from the surface by cracks and pores [6-9]. Another important process at the particle level is the transport of reactants to, and reaction products from, reaction sites within the particle. This process is diffusion governed, and is limited by the size and porosity of the ore particle, the diffusion gradient, and the diffusivity of the species. Finally, at the grain scale, the chemical and electrochemical interactions at the grain surface determine the leaching kinetics [10]. This paper presents the

Table 1: Chemical characteristics of G-II Uranium residue.

\begin{tabular}{|c|c|c|c|c|c|c|c|c|c|c|c|c|}
\hline Oxide & $\mathrm{SiO}_{2}$ & $\mathrm{Fe}_{2} \mathrm{O}_{3}$ & $\mathrm{FeO}$ & $\mathrm{TiO}_{2}$ & $\mathrm{CaO}$ & $\mathrm{MgO}$ & $\mathrm{Al}_{2} \mathrm{O}_{3}$ & $\mathrm{MnO}$ & $\mathrm{Na}_{2} \mathrm{O}$ & $\mathrm{K}_{2} \mathrm{O}$ & $\mathrm{P}_{2} \mathrm{O}_{5}$ & *L.O.I \\
\hline Wt \% & 75 & 1.83 & 0.33 & 0.11 & 0.9 & 0.16 & 10.4 & 0.01 & 1.2 & 3.9 & 0.3 & 1.9 \\
\hline
\end{tabular}

${ }^{*}$ L.O.I. = loss on ignition

Table 2: Trace elements analysis of G-II Uranium residue.

\begin{tabular}{|c|c|c|c|c|c|c|c|c|c|}
\hline Element & $\mathrm{Cu}$ & $\mathrm{Mo}$ & $\mathrm{Ni}$ & $\mathrm{pb}$ & $\mathrm{Zn}$ & $\mathrm{Zr}$ & $\mathrm{Nb}$ & $\mathrm{Ba}$ & 24 \\
\hline $\mathrm{Ppm}$ & 65 & 222 & 105 & 270 & 390 & 241 & 85 \\
\hline
\end{tabular}

\section{Leaching processes}

Agitation leaching test: The lab scale leaching tests were conducted on Gattar residue of $85 \mathrm{ppm}$ uranium by taking 10 g sample in each experiment. Leaching tests were carried out by varying one parameter at a time, keeping other leaching conditions constant for a period of 4 hours. Temperature at room temprature, liquied to solid ratio changed to $0.5,1.0,2.0$ and 3.0 solid, grind size grounded of $-20 \sim+10,-10 \sim+5,-5 \sim+2 \&-2 \mathrm{~mm}$ and lixiviant sulphuric acid solution with concentration range from $10-60 \mathrm{~g} / \mathrm{L}$. The reactor volume decreased by $5 \mathrm{ml}$ each time a sample was taken for uranium concentration analysis. Solid residue was washed with acidified water twice then dried in oven at $110^{\circ} \mathrm{C}$ and then analyzed for unleached uranium to know leachability at fixed time intervals.

Column percolation leaching: All types of leaching experiments were performed in polyvinyl chloride (PVC) columns: $10 \mathrm{~cm}$ internal diameter (D) and $125 \mathrm{~cm}$ height $(\mathrm{H})$, $\mathrm{H} / \mathrm{D}$ ratio about 12.5 In percolation leaching the ratio of the internal diameter of the column (D) to the particle size of ore (d) is significant. The ratio $\mathrm{D} / \mathrm{d}>10$ must be established to avoid the solution running down along the walls of the column [13]. Packing of these columns were divided into three different

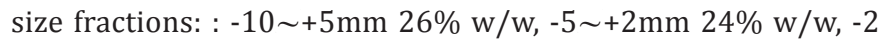
$\mathrm{mm} 50 \% \mathrm{w} / \mathrm{w}$ and the height of the loaded mineralization was measured to be $900 \mathrm{~mm}$. The drip irrigation method was used. The daily irrigation time of leaching was $10 \mathrm{~h}$ and the sprinkling floe rate, was $0.8 \mathrm{~L} / \mathrm{h}$. The leaching was carried out at room temperature. The leach solution was collected to determine volume, uranium concentration and $\mathrm{pH}$ value. When the uranium study of the leaching process for the recovery of the uranium present in the residues of the vat leaching from Gattar area.

\section{Chemical characteristics of investigated material}

To make the uranium residue more susceptible to high uranium extraction by leaching, solid residue must be crushed and grounded to produce particles size $-0.2 \mathrm{~mm}$ that can be readily slurred and to expose the uranium minerals to the lixiviant. The chemical composition of the samples of the uranium mineralization studied was determined in Nuclear Material Authority (NMA). The basic components of the ores are specified in Tables $1 \& 2$. The uranium and accompanying elements was determined by using inductively coupled plasma and volumetry of $\mathrm{H}_{2} \mathrm{SO}_{4}-\mathrm{TiCl}_{3}-\mathrm{NH}_{4} \mathrm{VO}_{3}[11,12]$.

\section{Experimental}

concentration in the leach solution was below $10 \mathrm{mg} \mathrm{L}^{-1}$, the leaching was completed and the leached residue was collected to determine the content of uranium. For the control, 10-30 $\mathrm{g} \mathrm{L}^{-1}$ $\mathrm{H}_{2} \mathrm{SO}_{4}$ was used for the leaching of the same uranium ore under the same conditions.

Analysis methods of uranium (Volumetric): Uranium was analyzed in the corresponding aqueous phases using Arsenazo III reagent under different conditions [14]. For this purpose, a Lambada UV/VIS spectrophotometer (Perkin-Elmer, USA) was used. The reagent $\mathrm{H}_{2} \mathrm{SO}_{4}, \mathrm{AR}, 6 \mathrm{~mol} / \mathrm{L}$; Titanium Chloride, $\mathrm{AR},\left(\mathrm{TiCl}_{3}\right)$ 15- 20\%; Sodium nitride, 15\% ; The urea, 40\%; O-Phenanthorline ferrous indicator, $0.15 \mathrm{~g}$ O-Phenanthorline and $0.07 \mathrm{~g}$ ferrous sulphate heptahydrate dissolved in $100 \mathrm{ml}$ $\mathrm{H}_{2} \mathrm{O}$. Uranium standard solution and ammonium vanadium acid standard solution [12].

\section{Results and Discussion}

\section{Uranium distribution in residue(tailing)}

According to Ficks Law [15], the mass transfer rate of lixiviants diffusing to unit area of mineral can be written as

$$
\mathrm{V}_{\mathrm{D}}=\mathrm{d}[\mathrm{A}] / \mathrm{dt}=\mathrm{D}\{[\mathrm{A}]-[\mathrm{Ai}]\} / \mathrm{L}=\mathrm{KD}\{[\mathrm{A}]-[\mathrm{Ai}]\}
$$

$\mathrm{V}_{\mathrm{D}}$ : Diffusing rate, $[\mathrm{A}]$ : Concentration on the surface of mineral. $\left[A_{1}\right]$ : Lixiviant concentration on the surface of mineral. L: Thickness of diffusion layer. D: Diffusion coefficient. $K_{D}$ : A constant of diffusion or mass transfer, $\mathrm{K}_{\mathrm{D}}=\mathrm{D} / \mathrm{L}$ t: Leaching time.

Small particle size ore has a big specific surface area, more uranium minerals in small particle size ore can be exposed on 
its surface than those in big particle size ore, the thickness of diffusion layer of small particle size ore is small, so it has a high diffusing rate. The leaching rate is proportional to diffusing rate. During leaching, feed ore should be controlled below a definite size, one of the main purposes of laboratory study is to obtain the optimum particle size. Four types of particle sizes of GII uranium residue have respectively been studied in this test. The experimental results are shown in Table 3. The test results mentioned above indicate that particle size has a notable effect on leaching efficiency. Regarding to GII residue, the uranium extraction (based on solution) of $-50 \sim+20 \mathrm{~mm}$ residue sample is $160 \mathrm{ppm}$, but the leachability of uranium from $-5 \sim+2 \mathrm{~mm}$ residue sample is $55 \mathrm{ppm}$.So the average concentrations in the residue after grinding to $-2 \mathrm{~mm}$ was $85 \mathrm{ppm}$.

\section{Agitation Leaching Tailings}

For the sample from the vat leaching residue, the process variables investigated were: liquid/solid ratio, stirring time, type of leaching solution, ore particle top size and temperature.

Table 3: Uranium distribution in residue (Analysis of particle size of tailings is provided in Table after grinded to $-2 \mathrm{~mm}$ ).

\begin{tabular}{|c|c|c|}
\hline & Particle size $\mathbf{~ m m}$ & $\begin{array}{c}\text { Grade of residue, } \\
\mathbf{~} \mathbf{m g} / \mathbf{k g}\end{array}$ \\
\hline GII- & $-50 \sim+20$ & 160 \\
\hline & $-20 \sim+10$ & 90 \\
\hline & $-10 \sim+5$ & 75 \\
\hline & $-5 \sim+2$ & 45 \\
\hline
\end{tabular}

\section{Effect of particle size}

Table 4: Effect of grain size upon leaching efficiency of uranium from Gattar residue.

\begin{tabular}{|c|c|}
\hline Grain class size, $\mathbf{m m}$ & Leaching efficiency, $\%$ \\
\hline+20 & 47.8 \\
\hline $20-10$ & 58 \\
\hline $10-6.3$ & 81.5 \\
\hline $6.3-1.0$ & 84 \\
\hline $1.0-0.4$ & 85 \\
\hline $0.4-0.2$ & 85 \\
\hline
\end{tabular}

The influence of particle size of ore on the efficiency of uranium leaching process was studied preliminary tests of leaching of un-ground ores were conducted in stirring vessels with $40 \mathrm{~g} / \mathrm{l}$ solution of $\mathrm{H}_{2} \mathrm{SO}_{4}$ Table 4 . Six fractions with different granulations were tested: $-0.2 \mathrm{~mm}, 0.2-0.4,0.4-0.63,0.63-1.0$, 1.0-5 and 5.0-10 $\mathrm{mm}$. Under above conditions, small evident influence of particle size on the metal leaching efficiencies was observed in the size ranged between $6.3-0.2 \mathrm{~mm}$ Table 4 . Usually, the literature shows that the decrease in particle size enhanced mineralogical and elemental distribution within the sizes and interaction of the minerals/ phases within the ore [16]. In the main time the influence of particle size on the uranium leaching efficiency was observed in the size ranged between 20 to $1.0 \mathrm{~mm}$ as shown in Table 4. Thus $-6.3 \mathrm{~mm}$ size was the optimum size.

\section{Effect of stirring time}

Stirring time should be experimentally chosen based on the characteristics of the ore e.g. type of mineralization, particle size $(-6.3 \mathrm{~mm})$ and leaching conditions. In this work, the time of leaching was changed from $15 \mathrm{~min}$ to $120 \mathrm{~min}$ in a series of tests under the same conditions. As it can be seen in Figure 1, after $60 \mathrm{~min}$ no increase of uranium leaching was observed. Thus 60 min was the optimum leaching time.

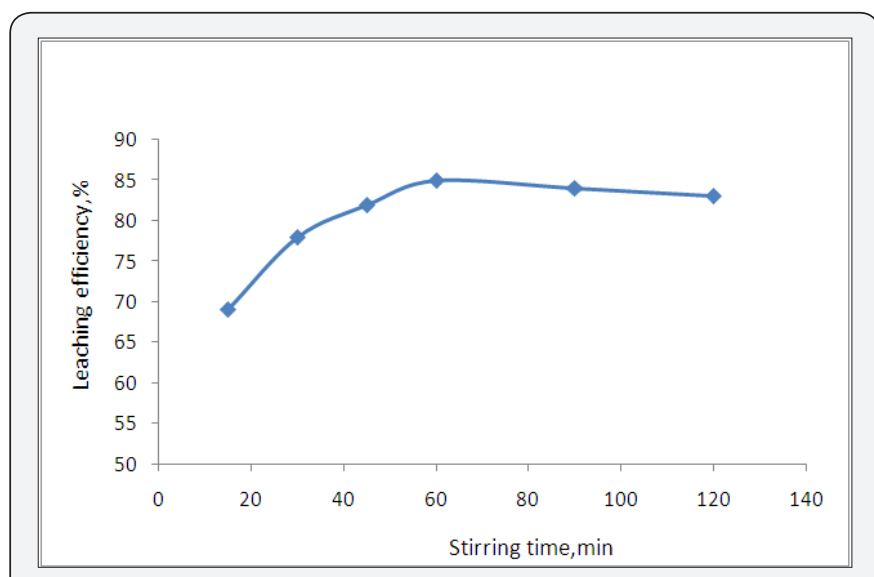

Figure 1: Uranium leaching efficiency (\%) as a function of stirring time (min).

\section{Acid concentration}

Selection of the optimum acid concentration is one of the most important phases of laboratory leach tests. Unless very high free acid concentrations are required (>10 g/L), suggesting that the gangue is relatively unreactive, experiments conducted under conditions of controlled $\mathrm{pH}$ are the most useful. Accurate control (to $\pm 0.1 \mathrm{pH}$ unit or better) is essential as the reactivity of certain gangue minerals (e.g. chlorite) is extremely sensitive to acid concentration [17]. In sulphate solution, the maximum dissolution rate of $\mathrm{UO}^{2}$ occurs at $\mathrm{pH}_{2}$ [18]. For other uranium minerals, a lower $\mathrm{pH}$ is usually required to achieve a satisfactory leaching rate.

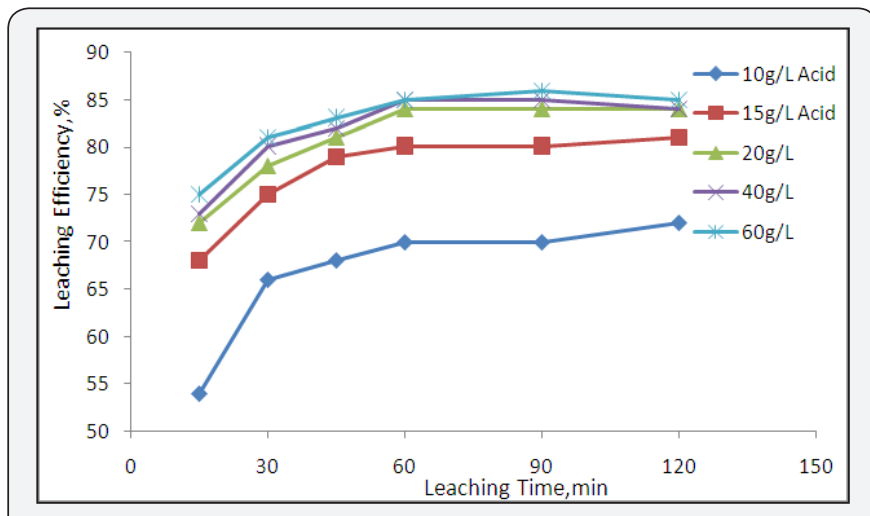

Figure 2 : The relationship between leaching times and leaching efficiency at different acid concentration.

The leaching efficiency as functions of leaching times and acid strength are displayed in Figure 2. The extraction of uranium increases steadily in the first 15-60 min of leaching. 
From $60 \mathrm{~min}$ to $240 \mathrm{~min}$ of leaching, the extraction rate of uranium became nearly constant for all acid concentrations. A plot of the percentage of leached uranium against sulphuric acid concentration is presented in Figure 2 on the condition that $10 \mathrm{~g}$ of uranium mineral ore was leached for $1.0 \mathrm{~h}$ at room temperature. The results indicated that the dissolution of uranium into liquid, increased rapidly with increasing in concentration of sulfuric acid from 10 to $20 \mathrm{~g} / \mathrm{l}$. The leaching recovery proportionally increased from $70 \%$ to $84 \%$ when increasing acid concentration between 20 to $60 \mathrm{~g} / \mathrm{l}$, uranium extraction degree increased only for $3 \%$. It was explained that further increasing of acid concentration slightly effect for recovery of uranium but significantly for consumption. Based on this test, the optimal concentrations of sulphuric acid for recovery uranium is $20 \mathrm{~g} / \mathrm{l}$.

\section{Effect of solid/ liquid ratio}

Selection of proper liquid to solid ratio (the volume of lixiviant to weight of ores) is important for optimization the leaching process. The effect of the liquid to solid ratio depends on e.g. grain distribution and free surface. For this reason it was necessary to test the effect of liquid to solid ratio on leaching operations of Gattar residue. This effect was significant as it shown on Figure 3. The above results indicate that the liquiedsolid ratio after $0.5: 1.0$ does not have remarkable effect on dissolution rate of uranium. Thus L/S 1:1 ratio was the optimum liquied-solid ratio.

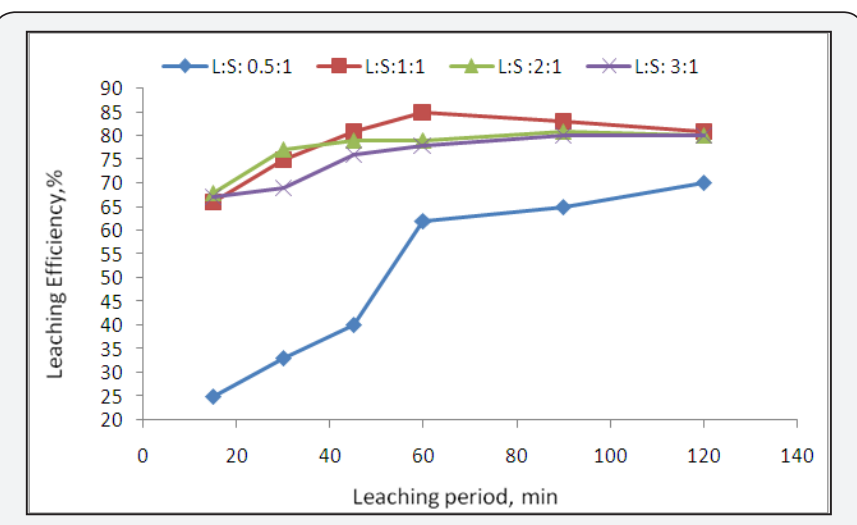

Figure 3 : Effect of liquid to solid ratio on leaching efficiency.

\section{Column leaching test}

During the column leaching process with $\mathrm{H}_{2} \mathrm{SO}_{4}$, the $\mathrm{pH}$ value of the leach solution declined rapidly and was then maintained at 1.5 after 5 days as in Figure 4. The higher $\mathrm{pH}$ at the beginning was a reason of remaining washing water in the column. The uranium recoveries was $83.90 \%$,the majority of iron element was in the ferric state when the oxidation potential was over 400 $\mathrm{mV}$, which was more favorable for uranium leaching [19]. On the first three days, the uranium minerals on the surface of the ores were dissolved quickly by $\mathrm{H}_{2} \mathrm{SO}_{4}$, and the uranium concentration in the leach solution increased rapidly to its maximum. $\mathrm{H}_{2} \mathrm{SO}_{4}$ could only react with U(VI) to form soluble complexes [20]. When the uranium minerals on the surface of the ores were almost dissolved, the leaching agents could be accessible to the uranium minerals left through the micro fissures and micro pores within ore particles. In this stage $\mathrm{H}_{2} \mathrm{SO}_{4}$ diffused slowly into the inner parts of the ore particles via the micro fissures and micro pores and then reacted with the accessible uranium minerals within the ore particles [21].

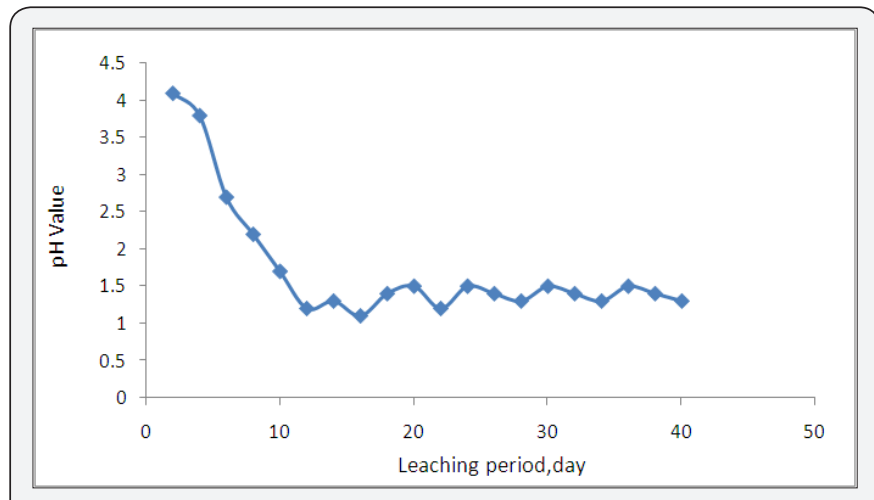

Figure 4 : Variation of $\mathrm{pH}$ of leach solution with time.

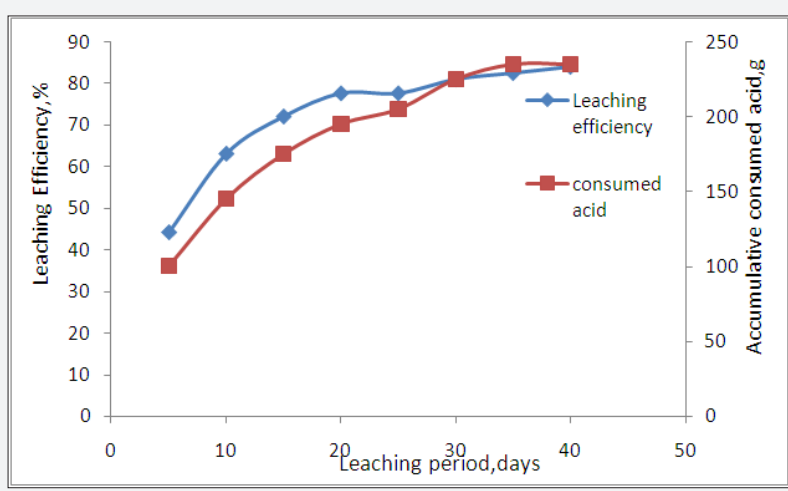

Figure 5 : Variation of Leaching efficiency and acid consumption with leaching period.

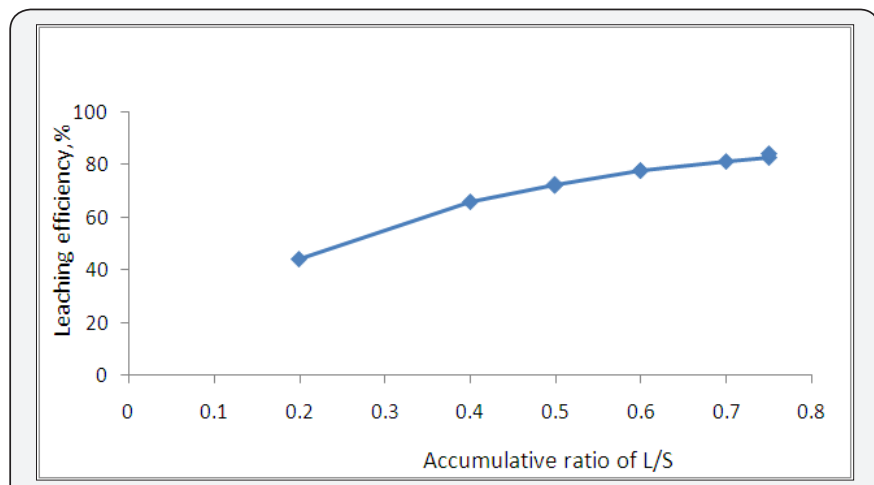

Figure 6 : Relation between the leaching efficiency and L/S of column leaching.

As a result, the uranium concentrations in the leach solutions were maintained at the relatively low levels from the 2 nd to 4 th day. The column leaching process extended for 38 days giving total leached uranium attaining about $1.09 \mathrm{~g}$ in $9.8 \mathrm{~L}$ pregnant solutions with leaching efficiency about $83.9 \%$ while the total uranium content in $15 \mathrm{~kg}$ residual inventory to $1.3 \mathrm{~g}$. Their cumulative results are shown in the Figure 5. From Figure 5, it 
is evident that accumulative amount of $\mathrm{H}_{2} \mathrm{SO}_{4}$ acid equivalent to about $230 \mathrm{~g}$ was required for leaching $15 \mathrm{~kg}$ residue ore quantity . This indicates that each $\mathrm{kg}$ ore consumed15.3g acid in the same time the liquid /solid ratio was 0.75 as shown in Figure 6. Leaching process was stopped when the concentration of uranium in the lechate solution decreased to less than $20 \mathrm{ppm}$.

\section{Conclusion and Recommendation for Future Work}

Uranium is extracted effectively from the pre treated uranium-bearing granite ores after re crashing to- $10 \mathrm{~mm}$, using $20 \mathrm{~g} / \mathrm{l}$ lixiviant sulphuric acid. The dissolution of uranium in the column under acid leaching conditions reached a maximum value of $83.9 \%$. Obviously economic process point of view in plant increase in sulphuric acid to $40 \mathrm{~g} / \mathrm{l}$ is costlier than minor increase in leachability. Leachability was slightly higher with ore grind size of $<-3 \mathrm{~mm}$, however excess grinding is not economical as grinding is the most expensive step in uranium processing. For pilot plant process in future, while conducting percolation or heap leaching studies on a large scale of uranium extraction from residue, economic aspects of uranium recovery must be kept in view and studies on a large scale and putting up of a large plants should be undertaken only after economic feasibility studies have been made.

\section{Acknowledgement}

The authors are thankful to Prf. Khalid Fouad Mahmoud, Chairman of Yellow Cake refining Department and supervisor of Uranium extraction project, Qattar, Egypt for his constant encouragement and interest in this work.

\section{References}

1. Taylor A (2008) Review of Uranium industry developments in 20072008. ALTA Uranium Conference, Perth.

2. Liu Jian, Fan Bao-Tuan, Zhang, Chuan-Jing (2001) Semi-commercial experiment study of bacteria heap leaching in Fuzhou Uranium. Mine [J] Uranium mining and Metallurgy 20(1): 15-27.

3. Li, Wei-Zhong, Peng, Xiao-Hua (1999) The application and optimization on the heap leaching of mullock in Dexing Copper. Mine [J] Hydrometallurgy of China 19(1): 29-33.

4. Yousef Ghorbani, Megan Becker, Aubrey Mainza, Jean-Paul Franzidis, Jochen Petersen (2011) Large particle effects in chemical/biochemical heap leach processes. J Minerals Engineering 24(11): 1172-1184.

5. Merrit RC (1971) Extractive Metallurgy of Uranium. Colorado School of Mines Research Institute.

6. Liddell KC (2005) Shrinking core models in hydrometallurgy: what students are not being told about the pseudo-steady approximation. Hydrometallurgy 79(1-2): 62-68.
7. Malmstrom ME, Berglund S, Jarsjo J (2008) Combined effects of spatially variable flow and mineralogy on the attenuation of acid mine drainage in groundwater. Applied Geochemistry 23(6): 1419-1436.

8. Sracek O, Gelinas P, Lefebvre R, Nicholson RV (2006) Comparison of methods for the estimation of pyrite oxidation rate in a waste rock pile at Mine Doyon site, Quebec, Canada. Journal of Geochemical Exploration 91(1-3): 99-109.

9. Stromberg B, Banwart S (1999) Experimental study of acidityconsuming processes in mining waste rock: some influences of mineralogy and particle size. Applied Geochemistry 14(1): 1-16.

10. Harneit K, Goksel A, Kock D, Klock JH, Gehrke T, et al. (2006) Adhesion to metal sulfide surfaces by cells of Acidithiobacillus ferrooxidans, Acidithiobacillus thiooxidans and Leptospirillum ferrooxidans. Hydrometallurgy 83(1-4): 245-254.

11. Chajduk E, Bartosiewicz I, Pyszynska M, Chwastowska J, PolkowskaMotrenko H (2013) Determination of uranium and selected elements in Polish dictyonema shales and sandstones by ICP-MS. J Radioanal Nucl Chem 295(3): 1913-1919.

12. Jin-hui Yang, Shi-liang Dai, Xiao-kang Pan, Li Liu, Shu-kui Zhou, et al. (2014) Determination of uranium in ore with volumetry of $\mathrm{H}_{2} \mathrm{SO}_{4}-\mathrm{TiCl}_{3}-$ $\mathrm{NH}_{4} \mathrm{VO}_{3}$. Applied Mechanics and Materials 511-512: 12-16.

13. Abhilash, Pandey BD (2013) Microbially assisted leaching of uranium - a review, Mineral Processing and Extractive Metallurgy Review. An International Journal 34(2): 81-113.

14. Marczenko Z (1976) Spectrophotometric determination of elements. Halsted, a Division of John Wiley \& Sons Inc., New York.

15. Shackelford CD, Daniel DE (1991) Diffusion in saturated soil. I: Background. Journal of Geotechnical Engineering 117(3): 467-484.

16. Ghorbani Y, Becker M, Mainza A, Franzidis JP, Petersen J (2011) Large particle effect in chemical/biochemical heap leach processes-A review. Mineral Eng 24(11): 1172-1184.

17. Ring RJ (1979) Leaching characteristics of Australian uranium ores. Australas Inst Min Metall Proc 272: 13-23.

18. Nicol MJ, Needes CRS, Finkelstein NP (1975) Electrochemical model for the leaching of uranium dioxide - 1 . Acid media. Leaching and Reduction in Hydrometallurgy Instn of Mining and Metallurgy, London $1-11$.

19. International Atomic Energy Agency (1990) IAEA's Division of Nuclear Fuel Cycle and Waste Managment. Technical reports series No. 313: Manual on laboratory testing for uranium ore processing, first ed. International Atomic Energy Agency, Vienna.

20. Du Preez JGH (1989) A Review of the industrial processes involving uranium-from the ore to the reactor. Radiat Prot Dosim 26(1-4): 7-13

21. Yin SH, Wu AX, Hu KJ, Wang HJ (2011) Solute transportation mechanism of heap leaching and its influencing factors. J Cent South Univ Technol 42: 1092-1098. 
(C) Commons Attribution 4.0 License BY DoI: 10.19080/OMCIJ.2018.04.555652

\section{Your next submission with Juniper Publishers} will reach you the below assets

- Quality Editorial service

- Swift Peer Review

- Reprints availability

- E-prints Service

- Manuscript Podcast for convenient understanding

- Global attainment for your research

- Manuscript accessibility in different formats ( Pdf, E-pub, Full Text, Audio)

- Unceasing customer service

Track the below URL for one-step submission https://juniperpublishers.com/online-submission.php 